Preface

\title{
Free Tissue Transfer Reconstruction
}

Yadranko Ducic, MD, FRCS(C), FACS ${ }^{1}$

1 Otolaryngology and Facial Plastic Surgery Associates, Fort Worth, Texas

Semin Plast Surg 2019;33:3-4.

Free flap reconstruction has evolved from something done rarely and in few hands to becoming a staple of reconstruction in the tool box of reconstructive surgeons all over the body. In this issue, we are blessed to have the pleasure of having a broad field multispecialty approach to some of the most complex of defects reconstructed with free tissue transfer.
I hope that the readers will enjoy this special issue as much as we all did putting it together. Hopefully, it will serve as a nice reference when approaching large or complex defects all over the body.

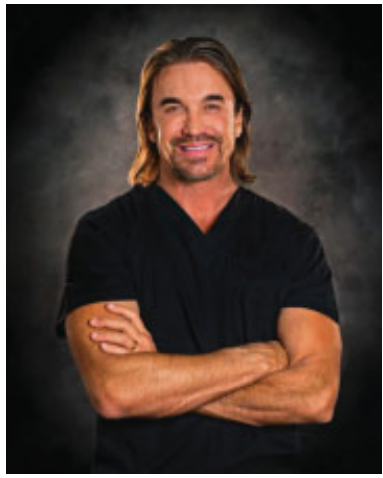

Yadranko Ducic, MD, FRCS(C), FACS
Address for correspondence Yadranko Ducic, MD, FRCS(C), FACS, Department of Facial Plastic and Reconstructive Surgery, Otolaryngology and Facial Plastic Surgery Associates, 923

Pennsylvania Avenue, Suite 100, Fort Worth, TX 76104

(e-mail: yducic@sbcglobal.net).
Issue Theme Free Tissue Transfer Reconstruction; Guest Editor: Yadranko Ducic, MD, FRCS(C), FACS
Copyright (c) 2019 by Thieme Medical Publishers, Inc., 333 Seventh Avenue, New York, NY 10001, USA. Tel: +1(212) 584-4662.
DOI https://doi.org/ 10.1055/s-0039-1678522. ISSN 1535-2188. 